\title{
Vladimar Negovsky: The Father of Reanimatology
}

\author{
The Negovsky Memorial Lecture, Given at The Seventh Scientific Congress \\ of the European Resuscitation Council, Budapest September 2004
}

\author{
Douglas Chamberlain
}

I am very privileged to have been invited to give a lecture in memory of Professor Vladimir Negovsky who was truly a founder of resuscitation medicine and a very great man. I met him only once, at the first Scientific Congress of the European Resuscitation Council in Brighton in 1992, but he made a lasting impression on me despite the barrier of our different languages: with his stature and his natural dignity there was also kindness, modesty, and courtesy. We were all saddened by the news of his death in August 2003, within a day or so of that of his long-time friend Peter Safar - one of our other great heroes.

My lecture is in Negovsky's memory, and it is appropriate for me to refer to some of his details of his life, his work, and his opinions. But it cannot all be all about this great man, because I know only a fraction of his achievements. Too much remained hidden from those of us in the West during the difficult years of the 20th century. What we do know, however, demonstrates not only his interest and skill in resuscitation medicine but also his foresight and prescience. These were clearly reflected in the article written about him by his distinguished friend, Peter Safar [1] as part of the 'Resuscitation Greats' series in the Journal Resuscitation; I have drawn heavily on this source. I will use these glimpses of his contributions and insight as a framework to indicate how far he was ahead of his time but also to show how poorly we have built on his achievements and those of the few other notable pioneers in resuscitation medicine. In the West, at least, this has been a poor relative of other clinical specialities. Few have made it their major professional interest, partly because for many reasons - research in this area is intrinsically difficult, but also partly because we have been slow to adopt and propagate new ideas that have clear merit and slow to abandon others that are based more on habit than on evidence. We still have much to learn, and we need more individuals with the clear vision, commitment, and objectivity that was shown by Negovsky. To a degree, then, my message relates not so much to his achievements as to how slow we have been in making progress, as about how many false notions have held sway, and about how much remains to be done. Negovsky, Safar, and a handful of others led the way: it is for us to follow.

Vladimir Negovsky was born in the Ukraine into a large family in 1909, and graduated as a

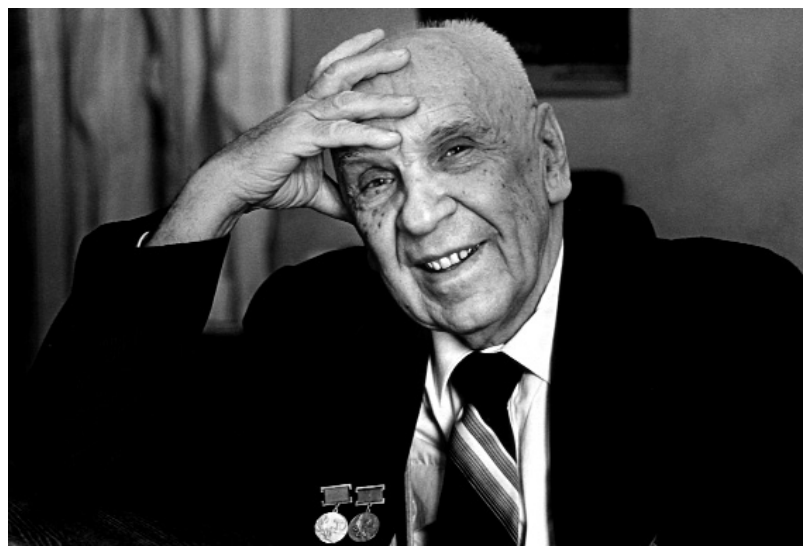

Academician of RAMS V. A. Negovsky

physician in Moscow in 1933. He founded the first resuscitation research laboratory only three years later. This was no whim, but represented a dedication to a branch of medicine that was as yet unrecognized. In 1943 - during a hugely destructive world war which was so far foreign to his own ideals - he published his Thesis on the pathophysiology and reversal of death [2], and in 1961 he declared the birth of a new science of reanimatology at an international conference on traumatology here in Budapest [3]. He worked ceaselessly at the development of the new science and broadened its scope beyond the immediacy of acute events. The Concept of Post Resuscitation Disease that became available in the West in 1983 [4] was another landmark for scientists who were by then working in the field. Negovsky remained active in reanimatology almost until he died at the age of 92 .

Over the two-thirds of a century of his work in the field, Negovsky published over 300 papers. Sadly, only a minority are readily available in Western Europe - the work was done before the wonders of the Internet helped to break down linguistic and national barriers. The scope of his interest was enormous, as can be shown from a list of the 15 broad topics that I know to have been included in his writings (Table 1), but there would have been many more.

- Asphyxia of the newborn

- Bipolar defibrillation (30 years sooner than it was common in the West)

- Civil disasters and rescue

- Diagnosis of brain death 
- Electric shock injury

- External chest compression (in the 1940s)

- Haemorrhage

- Hypothermia (in the 1960s)

- Myocardial infarction

- Near-death experiences

- Organ donation

- Pregnancy related accidents

- «Reoxygenation» (reperfusion) injury

- Shock

- Trauma

Negovsky distinguished in his writings the two phases of what we, in Western Europe, include in the term «resuscitation». The acute phase he called, graphically, «reanimation». But even more important to him - and neglected elsewhere for so long was the broader «reanimatology» that encompassed both the prevention and treatment of terminal states and post resuscitation disease and its management. The prevention of terminal states has only recently become fashionable outside Russia and Eastern Europe with the development of Medical Emergency Teams that have become widespread after publications from Australia [5].

Reanimatology itself embraces many aspects of the control of pathophysiology which include all of the following:

Control of vascular coagulopathy

Control of ventilation

Control of arrhythmias

Control of haemodynamics

Control of temperature

Control of metabolic abnormalities

Control of residual ischaemia

Control of residual electrical instability

All of these have a resonance with modern resuscitation science. But had Nekovsky's notable contributions been more widely appreciated, progress world-wide could have been faster. Resuscitation is replete with examples of real advances that were either ignored or briefly adopted but inappropriately forgotten [6]. It is of interest and salutary to consider these headings in a little more detail: we may not accept all of Negovsky's concepts but there is much that was ahead of its time. Even now, those of us in Western Europe have poor access to Negovsky's publications: doubtless many of the dates that we can ascribe to his prescient ideas from publications that are available to us reflect work that was published much earlier in his own country.

Control of vascular coagulopathy. Negovsky, in an American publication of 1974 [7], made the following interesting statement on coagulopathy:

With cessation of blood circulation, coagulation of the blood is significantly accelerated, and the coagulogram... manifests the traits characteristic of hypercoagulation... Some changes of the coagulogram do not disappear, and these changes are characteristic for pre-thrombosis state.

Only very recently is the importance of coagulopathy to the outcome of cardiac arrest becoming accepted. Even thirty years ago, however, it was not, entirely new. In 1954, Cromwell and colleagues described the occurrence of clotting in small blood vessels [8], and two years later the same group found that the administration of streptokinase could improve the survival of dogs with induced circulatory arrest [9]. But it was not until 1995 that Fischer and Hossman re-emphasized in the West the importance of a vascular no-reflow phenomenon after experimental cardiac arrest [10]. This was confirmed as an important complication of pre-hospital clinical cardiac arrest in 1997 [11] when massive fibrin formation was described as an impediment to restoration of an effective circulation. Even after intravascular clotting was found to be important in the pathophysiology of cardiac arrest, physicians were reluctant to use fibrinolysis as treatment because victims would almost invariably have had chest compressions: the trauma was seen as an important risk factor for serious haemorrhage. But gradually experience was gained of the use of fibrinolysis in patients who had had myocardial infarction complicated initially by cardiac arrest. The risk of haemorrhage was found to be small after limited [12] or even prolonged [13] cardiopulmonary resuscitation. This encouraged preliminary studies of fibrinolysis as a deliberate treatment of cardiac arrest $[14,15]$. A better neurological outcome was also noted when survivors of cardiac arrest had received fibrinolytic drugs $[16,17]$. Now a major international trial is under way to study the efficacy of fibrinolysis for cases of cardiac arrest that are not responsive to immediate defibrillation [18]. But even if fibrinolysis is shown to be of value in the current trial, much will remain to be explored: should the treatment be used only for refractory cardiac arrest; or for those who fail to regain consciousness quickly; or for all except those who respond quickly to defibrillation? We would have been much further along the path of establishing its role if the experimental work several decades ago by Negovsky and others had received more attention from physicians dealing routinely with cardiac arrest.

Control of ventilation. On ventilation, Negovsky had strong views as is shown by the following quotation [19]:

«After terminal states, brain-damaged patients need prolonged artificial ventilation. During unconsciousness, an early transition to spontaneous breathing is a mistake, and may be lethal»

Many of us can recall cases for whom recovery has been jeopardized by failure to institute artificial ventilation for cases of cardiac arrest with respiratory prob- 
lems or by premature withdrawal of ventilatory support. Negovsky's plea still demands emphasis. Respiratory support has dangers too that were not well recognized until recently, especially if hyperventilation is used, as has often been the case. It has been recommended to mitigate neurological damage both on experimental [20] and clinical [21] grounds. But controversy still surrounds the issue of constriction of cerebral blood vessels in response to hyperventilation: most would now ensure that it is avoided both after head injury [22] and cardiac arrest [23]. It has additional disadvantages that are of special importance for victims of cardiac arrest: inappropriate ventilation may limit the number of chest compressions, reduce diastolic coronary perfusion pressure and limit systemic flow by increasing intrathoracic pressure, and induce respiratory alkalosis that shifts the oxygen dissociation curve to the left [24]. This is not only a theoretical risk. Paramedics have been observed to be over-enthusiastic with ventilation to a degree that when replicated experimentally can prevent a successful outcome [25]. Negovsky would surely have agreed that the undoubted importance of judicious artificial respiratory support should not be extrapolated to hyperventilation on the grounds that some is good so more must be better!

Control of arrhythmias. The emphasis in the management of arrhythmias remains on defibrillation because this is where most benefit can be obtained. Negovsky was once more ahead of his colleagues in West. The following quotation confirms his interest in this subject [26]:

«Because of the negative effects of electric impulse therapy on the myocardium, ways of lowering the dose of defibrillation charge while preserving its efficacy have been sought. A method was found and used as a basis for creating defibrillators generating bipolar impulses»

Negovsky would not have been directly involved in this work, but he had Gurvich and Makaritchev as co-workers and was quoting a paper of theirs from 1967 [27], more than 20 years before bipolar defibrillation became popular in the West [28]! As a digression, one might mention that - in many respects - these years were not spent profitably in terms of effective control of arrhythmias. Only slowly has it become clear that antiarrhythmic drugs have little role in prophylaxis, with type I drugs in particular having a proarrhythmic effect [29]. In terms of the value of drugs we can be sure of the efficacy of cardioversion (ideally now with bipolar shocks!) for severe unstable rhythms, and we have reasonable observational evidence for the value of atropine. Amiodarone is the best bet for tachycardias [30] but we have no real evidence that it improves survival from critical situations. Beta blockade is under-used. Esmolol, that seems to have an ideal profile for many critical tachyarrhythmias, has been largely ignored, and a recent study showed that beta blockade of any sort was used in only 11\% of survivors admitted to one centre in the United Kingdom after cardiac arrest [31]. Yet the use of beta blockade predicts survival after cardiac arrest as shown in a recent multiple regression analysis [32], and its safety with careful use in heart failure - even with hypotension - is no longer in doubt [33]. I do not think that Negovsky with his powerful insight would have been impressed by this failure to exploit one of the few effective treatments for malignant arrhythmias, though I am not aware of any direct comments he might have made on this topic.

Control of haemodynamics. Negovsky had firm views on this topic as one might expect from his known interest in trauma. In this regard his views are not fully in accord with modern concepts [7].

«It is known that protracted hypotension, especially when preceded by un-replaced blood loss, can lead to irreversible damage of vitally important organs even before clinical death has set in»

Thus far all would agree, and again the point is worthy of emphasis. But this statement is followed by the assertion that arterial transfusion should be recommended if venous transfusion is inadequate accompanied by high doses of corticosteroids. Few would agree that arterial transfusion has any role save in very special circumstances, and the role of corticosteroids is at least very contentious. Even in cases of head injury for which their use has long been fashionable in some countries, recent evidence suggests that they may do more harm than good [34]. Our respect for Negovsky's prescience in so many matters related to resuscitation does not require that we accept all his statements uncritically; he would not have wished any to do so! But as with the control of arrhythmias, we have made little progress since the days that he was active and followed what my well be inappropriate paths. The value of an optimal filling pressure for hypotension is clear, though the meaning of optimal can vary according to the pathology. The true benefit that comes from vasoactive drugs is more open to question despite the continued enthusiasm for noradrenaline, dobutamine, dopamine, amrinone, and salbutalmol - which all have strong advocates. A recent opinion [35] is pertinent in this regard: that there is no evidence for the efficacy of any pressor drug, but that most would treat persisting hypotension with a systolic pressure of less that $70 \mathrm{mmHg}$, usually with dobutamine. Cardiac output is more important than blood pressure! This remains a valid - indeed pressing - area for research.

Control of temperature. This is a topical subject and views are still evolving. Negovsky, however, 
it seems, had vision that was lacking in the West. His first publication on the subject that was available in the West was entitled Resuscitation and artificial hypothermia, published in New York in 1962 [36]. I have been unable to obtain a copy but even the title indicates that he was one of the pioneers in therapeutic hypothermia whose ideas have taken so long to find acceptance. As long ago as 1954, experimental studies had shown that brain metabolism increased by $7 \%$ for every $1^{\circ} \mathrm{C}$ increase in temperature [37], and worse outcome was observed after cardiac arrest in the presence of fever [38]. Benefit from controlled hypothermia to those in coma was reported only a few years later $[39,40]$ and the topic was well reviewed in the New England Journal of Medicine in 1961 [41]. Yet randomized trials in victims of cardiac arrest were published only in 2002 $[42,43]$ with benefits in both cerebral function and mortality. They prompted an ILCOR advisory statement the same year [44] with the advice that «unconscious adult patients who have spontaneous circulation after out-of-hospital cardiac arrest should be cooled to $32 / 34^{\circ} \mathrm{C}$ for 12 to 24 hours when the initial rhythm was ventricular fibrillation»; it added that «such cooling may also be beneficial for other rhythms or in-hospital cardiac arrest». Yet even now this treatment has not been widely adopted in my own country. Why are we so slow to learn? It is not because the techniques are intrinsically difficult. Many relatively simple methods can be used as well as more complex ones. The choice includes those mentioned in the ILCOR report: external body cooling with ice packs; external local cooling of the head using a helmet device; intravascular infusions with, for example ice-cold saline; and peritoneal or pleural cooling with intravascular heat exchangers. Control of temperature in critical care is not, however, simply a matter of lowering body temperature. Studies show that judicious increase in body temperature - at least to normal values - also has a role when haemorrhage is a problem in cases of trauma to combat platelet dysfunction [45], but this too remains poorly investigated and even controversial. While control of temperature was being disregarded, other methods of cerebral protection were explored and used with enthusiasm. They included the use of barbiturates [46], steroids [47], calcium channel blockers $[48,49]$. None was eventually shown to bring benefit.

Control of metabolic abnormalities. Negovsky's concepts went beyond what we generally regard as metabolic disturbances. With Zacs, he wrote [50]:

«The studies carried out at our institute over many years show that any terminal state, regardless of its etiology, is accompanies by «toxemia». The more severe or prolonged the tissue hypoxia, the higher are the levels of many toxic products in the blood»
Thus, whilst not forgetting the importance of acid-base balance, he also promoted the use of haemabsorption to remove toxic metabolites. Was Nekovsky once more ahead of his time? Until recently most in the West would not attach much credence to the notion of benefit by removing important toxic substances from the blood. But this may be set to change. In 2002, Weisfeldt and Becker [51] described three phases for the resuscitation after cardiac arrest: an electrical phase, a circulatory phase, and a metabolic phase. The last is in tune with Negovsky's concepts. For the metabolic phase, these influential scientists have made suggestions that include the use of bypass techniques to allow dilution of toxic metabolites. The value of this remains, however, to be proven. Metabolic abnormalities after cardiac arrest have a number of causes: some are due to the effect of ischaemia on tissues, some due to physiological responses, and some due to treatment. Hyperglycaemia is one complication that arises from endogenous causes such as catecholamine and steroid release, but often exacerbated by the administration of adrenaline. Until recently, it attracted little attention but is likely to be important. It has been recognized as a marker of increased mortality after cardiac arrest $[52,53,54]$ and is also a predictor of mortality after both myocardial infarction [55] and stroke [56], but in the past it has been considered an epiphenomenon - an association that was regarded as unlikely to have a causal role. In 2003, however, two studies $[32,57]$ showed by multivariate analysis that it does have an independent effect on mortality. The first publication seeking to explore the benefit of intensive glycaemic management of critically ill adult patients was published only in 2001 [58]. No major studies have been reported specifically in cardiac arrest.

Control of residual ischaemia. Although this topic interested Negovsky in his concern about postresuscitation disease, effective means of achieving it became available only later. Indeed, the importance of ischaemia and recent ischaemia as a cause of unexpected cardiac arrest has been uncertain. The reasons are clear. Pathological changes of infarction usually have no time to develop in cases of sudden death, and the reliable identification of recent thrombus in a coronary artery is so time consuming that it is not suitable as an epidemiological tool. The extensive experience of prehospital resuscitation in Seattle [59] suggested that recent ischaemia accounted for only about a half of all cases in those who survived. The remainder had no clinical, electrocardiographic, or enzymatic evidence of recent ischaemia. But survivors may not have been representative of the whole population with cardiac arrest. Moreover, this evidence ante-dated the understanding of plaque rupture and the electrical events that could follow complications such as 
platelet embolization. Spaulding and colleagues in Paris have now thrown new light on this topic [60]. They undertook coronary angiography immediately after admission on 75 consecutive victims of out-ofhospital arrest aged 30 to 75 whether or not they had regained consciousness. This study revealed that ischaemia was indeed the most common cause of sudden death in their population, though again some bias may have occurred because they were examining only survivors (but with severe ischaemia possibly more likely in those who died on scene). In those examined, $48 \%$ had a definite recent coronary occlusion, and $21 \%$ a likely recent occlusion. Other significant coronary disease was present in $2 \%$. There was no clinical evidence of coronary disease in $11 \%$ of those in whom it was demonstrated angiographically which adds weight to the assertion that careful evaluation of all survivors of unexpected cardiac arrest should be the norm. This matter is addressed in the next related section.

Control of residual electrical instability. Defibrillation addresses this problem to a large degree in the acute stages of resuscitation. But in the subsequent stage of managing post resuscitation disease, the available options came late in Nekovsky's working life and I am not aware of any of his writings in this area. Although powerful strategies are available to help prevent a recurrence of malignant arrhythmias in the survivors of cardiac arrest, they have been under-used in at least many European countries. Weston and colleagues reported in 1993 [61] that in Wales only three of 53 consecutive survivors of unexpected cardiac arrest had an electrophysiological study and none received an implantable defibrillator; 32 were not referred to a cardiologist. In a similar study from England published in 2000 [31], Pepper et al showed that of another 53 patients only eight had an electrophysiological study, six received an implantable defibrillator, but 29 were not seen by a cardiologist. The situation was little different in Sweden [62]. The cost of implantable defibrillators is likely to be a major problem in most European countries. A report in 2004 [63] showed that in the United States the rate of utilization was 169 per million population; Denmark led the way in Europe with $28 \%$ of this figure, but all other countries had rates below 25\% that of the American practice, some far below. It may or may not be inevitable, but appropriate treatment is being denied to many survivors of out of hospital cardiac arrest.

What should be done? One management strategy will not suit all cases [64], but we have good evidence that most cases of unexpected out-of-hospital cardiac arrest are due to coronary artery disease. Those known to have had a recent infarct may be at less risk of a recurrence than others [59], but angiography would be expected unless there are good reasons for avoiding detailed investigation; percutaneous intervention will follow in most cases and may be all that is required to remove vulnerability to malignant arrhythmias due to ischaemia. The situation will be less clear for survivors with documented ischaemia but no definite recent ischaemic event. The cause of a recent cardiac arrest will then be uncertain, and ideally an electrophysiological study will be carried out but with the possible need for an implantable defibrillator. This is the preferred policy for all cases warranting investigation if ischaemia is an unlikely aetiology.

The claim is well founded that we have much to do in order to improve the management of patients after the immediate treatment of cardiac arrest. In 2004 we should be seriously considering identifying the potential for short-acting beta blockers in the immediate post arrest phase, and be more enthusiastic about the use of oral agents long-term; we need to obtain real evidence of the value of adrenaline in the management of refractory cardiac arrest and the use of pressor agents for hypotension subsequently; the role of fibrinolysis in the management of cardiac arrest will need to be clarified even after the completion of an on-going international trial; the risk-benefit ratio of amiodarone in the management of malignant tachyarrhythmias remains uncertain with or without recent cardiac arrest; the indications for hypothermia need to be investigated further, particularly with regard to the best methods to use, and specifically - the optimal time to initiate therapy; the ideal control of blood glucose after cardiac arrest should be better defined and its potential value more widely known, with investigation of the importance of other toxic metabolic derangements; and best practice should be agreed and practised as widely as possible with regard to angiography, percutaneous coronary intervention, and the use of electrophysiological studies and implantable defibrillators. We are within sight of improving both prehospital management of cardiac arrest and aftercare; but we need commitment!

Negovsky had commitment: the list of his interests related to resuscitation is impressive. But there are two more of which I have made no mention so far. He was sensitive to the philosophy of his science. One illustration comes from a quotation dating from 1986 [65]:

«Life is our greatest gift. We must continue to struggle for people standing on the brink of life and death. Here lie the meaning and the aim of our science»

But even more important is his commitment to peace [66]:

«Our struggle for saving a life makes sense only if we live in peace, and prevent nuclear and space wars» 
Europe has changed hugely within the lifetime of many of us. The wars that so disfigured our continent within the lifetime of many of us would be unthinkable in the future. But the world is not at peace. Disputes that we would wish to be settled by sensible negotiation are still excuses for the use of weapons that have ever more potential for widespread destruction. Even within the borders of our own countries, acts of senseless terrorism bring unnecessary suffering and misery as

\section{References}

1. Safar P. The resuscitation greats. Vladimir Negovsky the father of 'reanimatology'. Resuscitation 2001; 49: 223-229.

2. Negovsky V. A. Resuscitation of the Organism: Agonal States and Clinical Death. Moscow: Unknown, 1943 (book in Russian). Published also in English in Amer. Rev. of Soviet Med.; 1945, Vol . 2; and 1946 Vol. 3 .

3. Negovsky V. A. International Traumatology Conference, Budapest. Traumatology and Orthopedics 1961; 3-4: 259.

4. Negovsky V. A., Gurvitch A. M., Zolotokrylina E. S. Postresuscitation disease. Amsterdam: Elsevier; 1983.

5. Hillman K., Parr M., Flabouris et al. Redefining in hospital resuscitation: the concept of the medical emergency team. Resuscitation 2001; 48 105-110.

6. Chamberlain D. Never quite there: a tale of resuscitation medicine Resuscitation 2004; 60: 3-11.

7. Negovskii $V$. In cardiac arrest and resuscitation. Ed. Stephenson 4th ed Mosby St Louis: Mosby St; 1974.

8. Crowell J. W., Lambright R. L., Scharpe G. P. Changes in coagulatuion time due to acute circulatory failure. Amer. J. Physiol. 1954; 179: 628.

9. Crowell J. W., Smith E. E. Effect of fibrinolytic activation on survival and cerebral damage following periods of circulatory arrest. Am. J. Physiol. 1956; 186: 283-285.

10. Fischer M., Hossmann K. A. No re-flow after cardiac arrest. Intensive Care Med 1995; 21: 132-141.

11. Gando $S$, Kameue T., Nanzaki $S$, Nakansishi $Y$. Massive fibrin formation with consecturive impairment of fibtrinolysis in patients with out-ofhospital cardiac arrest. Thromb. Haemost. 1997; 77: 278-282.

12. Tenaglia A. N., Califf R. M., Candela R.J. et al. Thrombotic therapy in patients requiring cardiopulmonary resuscitation. Am. J. Cardiol. 1991 68: 1015-1019.

13. van Campen L. C. M. C., van Leeuwen G. R., Verheught F. W. A. Safety and efficacy of thrombolysis for acute myocardial infarction in patients with prolonged out-of-hospital cardiopulmonary resuscitation. Am. J. Cardiol. 1994; 73: 9535.

14. Böttiger B. W., Bode C., Kern S. et al. Efficacy and safery of thrombolytic therapy after initially unsuccessful cardiopulmonary resuscitation: a prospective clinical trial. Lancet. 2001; 357: 1583-1585.

15. Lederer $W$., Lichtenberger $C$., Pechlaner $C$., et al. Recombinant tissue plasminogen activator during cardiopulmonary resuscitation in 108 patients with out-of-hospital cardiac arrest. Resuscitation 2001; 50 $71-76$.

16. Schreiber W., Sterz G. F., Muellner M. et al. Thrombolytic therapy after cardiac arrest and its effect on neurological outcome. Resuscitation. 2002; 52: 63-69.

17. Lederer W., Lichtenerger $C$., Pechlaner C. et al. Long-term survival and neurological outcome of patients who received recombinant tissue plasminogen activator during out-of-hospital cardiac arrest. Resuscitation. 2004;61:123-129.

18. Spöhr F. Arntz H. R., Bluhmki E. et al. An international multicentre trial protocol to assess the efficacy and safety of tenecteplase during cardiopulmonary resuscitation in patients with out-of-hospital cardiac arrest: The Thrombolysis in Cardiac Arrest (TROICA) study. Crit. Care Med. 2005; in the press.

19. Negovsky V. A. Postresuscitation disease. Crit. Care Med. 1988; 16 942-946.

20. Vanicky I., Marsala M., Murar J. et al. Prolonged postischemic hyperventilation reduces acute neuronal damage after $15 \mathrm{~min}$ of cardiac arrest in the dog. Neurosci. Lett. 1992; 135: 167-170.

21. Oertel M., Kelly D. F., Lee J. H. et al. Efficacy of hyperventilation, blood pressure elevation, and metabolic suppression therapy in controlling intracranial pressure after head injury. J. Neurosurg. 2002; 97: 1045-1053. occurred so recently in Russia when schoolchildren were the actual target of people set on evil [67]. This event, probably more than any other, caused all of us great anguish. As members of the European Resuscitation Council we cannot prevent all conflict but we must play our part in making in creating an ethos that makes it less likely and less destructive. We must all be ambassadors for peace. This is the best way of honouring the memory of Vladimir Negovsky.

22. Muizelaar J. P., Marmarou A., Ward J. D. et al. Adverse effects of prolonged hyperventilation in patients with severe head injury; a randomized clinical trial. J. Neurosurg. 1991; 75: 731-739.

23. Buunk G., van der Hoeven J. G., Meinders A. E. Cerebrovascular reactivity in comatose patients resuscitated from a cardiac arrest. Stroke 1997; 28: $1569-1573$.

24. Pitts S., Kellermann A. L. Hyperventilation during cardiac arrest. Lancet 2004; 364: 313-316.

25. Aufderheide T. P., Sigurdsson G., Pirrallo R. G. et al. Hyperventilationinduced hypotension during cardiopulmonary resuscitation. Circulation 2004; 109: 1960-1965.

26. Negovsky V. A. Fifty years of the institute of general reanimatology of the USSR Academy of Medical Sciences. Crit. Care Med 1988; 16 : 287-291.

27. Gurvich N. I., Makarchev V.E. Defibrillation of the heart with biphasic electrical impulses. Kardiologya 1967; 7: 109-112.

28. Winkle R. A., Mead R. H., Ruder M. A. et al. Improved low energy defibrillation efficacy in man with the use of a biphasic truncated exponential waveform. Am. Heart. J. 1989; 117: 122-127.

29. Moosvi A. R., Goldstein S., VanderBrug Medendorp S. et al. Effect of empiric antiarrhythmic therapy in resuscitated out-of-hospital cardiac arrest victims with coronary artery disease. Am. J. Cardiol. 1990; 65: 1192-1197.

30. The CASCADE Investigators. Randomized antiarrhythmic drug therapy in survivors of cardiac arrest (the CASCADE study). Am. J. Cardiol. 1993; 72: 280-287.

31. Pepper C. B., Batin P. P. D., Bannister J. et al. Antiarrhythmic management and implantable defibrillator use in survivors of prehospital cardiac arrest without myocardial infarction in West Yorkshire. Heart 2000; 83: 312-315.

32. Skrifvars M. B., Pettilä V., Rosenberg P. H. et al. A multiple logistic regression analysis of in-hospital factors related to survival at six months in patients resuscitated from out-of-hospital ventricular fibrillation. Resuscitation 2003; 59: 319-328.

33. Rouleau J. L., Roecker E. B., Tendera M. et al. Influence of retreatment systolic blood pressure on the effect of carvedilol in patients with severe chronic heart failure. The carvedilol prospective randomized cumulative survival (COPERNICUS) study. JACC 2004; 43: $1423-1429$.

34. Roberts I., Yates D., Sandercock P. et al Effect of intravenous corticosteroids on death within 14 days in 10008 adults with clinically significant head injury (MRC CRASH trial): randomised placebo-controlled trial. Lancet 2004; 364: 1321-1328.

35. Vasquez A., Kern K. B., Hilwig R. W. et al. Optimal dosing of dobutamine for treating post-resuscitation left ventricular dysfunction. Resuscitation 2004; 61: 199-207.

36. Negovsky V. A. Resuscitation and artificial hypothermia (USSR). N. Y.: Consultants Bureau, 1962 (in English).

37. Rosomhoff H. L., Holaday D. A. Cerebral blood flow and cerebral oxygen consumption during hypothermia. Amer. J. Physiol. 1954; 179: 85

38. Takino M., Okada Y. Hyperthermia following cardiopulmonary resuscitation. Intensive Care Med. 1991; 17: 419-420.

39. Benson D. W., Williams G. R., Spencer F. C., Yates A. J. The use of hypothermia after cardiac arrest. Anesth. Analg. 1958; 38: 423-428.

40. Williams G. R., Spencer F. C. The clinical use of hypothermia following cardiac arrest. Ann. Surg. 1959; 148: 462-466.

41. Smith R. M., Stetson J. B. Therapeutic hypothermia. N. Engl. J. Med. 1961; 265: 1097-1103, 1147-1151.

42. Bernard S. A., Gray T. W., Buist M. D. et al. Treatment of comatose survivors of out-of-hospital cardiac arrest with induced hypothermia. New Engl. J. Med. 2002; 346: 557-563.

43. The Hypothermia after Cardiac Arrest Study Group. Mild hypothermia to improve the neurologic outcome after cardiac arrest. New Engl. J. Med. 2002; 346: 549-556. 
44. Nolan J. P., Morley P. T., Vanden Hoek et al. Therapeutic hypothermia after cardiac arrest. An advisory statement by the advanced life support task force of the international liaison committee on resuscitation. Resuscitation 2003; 57: 231-235.

45. Wolberg A. S., Meng Z. H., Monroe D. M. et al. A systemic evaluation of the effect of temperature on coagulation enzyme activity and platelet function. J. Trauma 2004; 56: 1221-1228.

46. Brain resuscitation trial 1 study group. Randomized clinical study of thiopental loading in comatose survivors of cardiac arrest. New Engl. J. Med. 1986; 314: 397-403.

47. Jastremski M., Sutton-Tyrell K., Vaagenes P. et al. Glucocorticoid treatment does not improve neurological recovery following cardiac arrest. JAMA 1989; 262: 3427-3430.

48. Roine R. O., Kaste M., Kinnunen A. et al. Nimodipine after resuscitation from out-of-hospital ventricular fibrillation. A placebo-controlled, double-blind, randomized trial. JAMA 1990; 264: 3171-3177.

49. Brain resuscitation trial 2 group. A randomized clinical study of a calcium-entry blocker (lidoflazine) in the treatment of comatose survivors of cardiac arrest. N. Engl. J. Med. 1991; 324: 1225-1231.

50. Negozsky V. A, Zaks I. O. Endogenous intoxication on the pathogenesis of postresuscitation disease. Anaesthesiol. Reanim. 1982; 3: 27.

51. Weisfeldt M. L, Becker L. B. Resuscitation after cardiac arrest. JAMA 2002; 288: 3035-3038.

52. Longstreth W. T., Inui T. S. High blood glucose level on hospital admission and poor neurological recovery after cardiac arrest. Ann. Neurol. 1984; 15: 59-63.

53. Calle P. A., Buylaert W. A., Vanhaute O. A. et al. Glycemia in the postresuscitation period. Resuscitation 1984;17 (Suppl 1): S181-188.

54. Mullner M., Sterz F., Binder M. et al. Blood glucose concentration after cardiopulmonary resuscitation influences functional neurological recovery in human cardiac arrest survivors. J. Cereb. Blood Flow Metab. 1997; 17: 430-436.

55. Wahab N. N., Cowden E. A., Pearce N.J. et al. Is blood glucose an independent predictor of mortality in acute myocardial infarction in the thrombolytic era? J. Am. Coll. Cardiol. 2002; 40: 1748-1754.
56. Williams L. S., Rotich J., Oi R., Fineberg N. et al. Effects of admission hyperglycemia on mortality and costs in acute ischemic stroke. Neurology; 2002: 59: 67-71.

57. Langelle A., Tyvold S. S., Lexow K. et al. In-hospital factors associated with improved outcome after out-of-hospital cardiac arrest. A comparison between four regions in Norway. Resuscitation 2003; 56 : $247-263$

58. van den Berghe G., Wouters P., Weekers F. et al. Intensive insulin therapy in the critically ill patients. N. Engl. J. Med. 2001; 345: 1359-1367

59. Cobb L. A., Baum R. S., Alvarez H. et al. Resuscitation from out-of-hospital ventricular fibrillation; 4 hears follow-up. Circulation 1975; 52 (Suppl 3): 223-228.

60. Spaulding C. M., Joly L. M., Rosenberg A. et al. Immediate coronary angiography in survivors of out-of-hospital cardiac arrest. N Engl J Med 1997; 336: 1629-1633.

61. Weston C. F. M., Avery P. G., Stephens M. R. Mangement of hospital survivors of pre-hospital ventricular fibrillation. J. Roy Coll. Phys. 1993; 27: $242-246$

62. Engdahl $J$ Abrahamsson $P$ Baing A et al Is hospital care of major importance for outcome after out-of-hospital cardiac arrest? Experience acquired from patients with out-of-hospital cardiac arrest resuscitated by the same Emergency Medical Service and admitted to one of two hospitals over a 16-year period in the municipality of Göteborg. Resuscitation 2000: 43: 201-211.

63. Mond H. G., Irwin M., Morillo C., Ector $H$. The world survey of cardiac pacing and cardioverter defibrillators: calendar year 2001. Pace 2004; 27: 955-964.

64. Brooks R., McGovern B. A., Garan H, Ruskin J. N. Current treatment of patients surviving out-of-hospital cardiac arrest. JAMA 1991; 265: 762-768.

65. Negozsky V. A. Essays on reanimatology. Moscow; Meditsina; 1986: 253.

66. Negovsky V. Crit. Care Med. 1988; 16: 290.

67. Baker P., Glasser $S$. B. Russia school siege ends in carnage hundreds die as troops battle hostage takers. Washington Post 4 September 2004

\title{
ВЛАДИМИР НЕГОВСКИЙ: ОТЕЦ РЕАНИМАТОЛОГИИ
}

\section{Лекция памяти В. А. Неговского, прочитанная на VII Научном Конгрессе Европейского Совета по Реаниматологии в Будапеште, сентябрь 2004 г.}

\author{
Дуглас Чемберлен
}

Для меня большая честь быть приглашенным и прочитать лекцию, посвященную памяти В. А. Неговского, который являлся подлинным основателем реаниматологии и великим человеком. Я встретился с ним всего лишь один раз на I Научном Конгрессе Европейского Совета по Реаниматологии в Брайтоне в 1992 г., но эта единственная встреча произвела на меня неизгладимое впечатление, несмотря на языковой барьер: его высокое положение в науке и природная гордость не мешали ему быть одновременно и доброжелательным, и сдержанным, и любезным. Все мы были глубоко потрясены известием о его смерти 2 августа 2003 г., которая случилась за день до смерти его давнего друга Питера Сафара, еще одного видного ученого.

Моя лекция посвящена памяти В. А. Неговского и в ней следует рассказать о некоторых подробностях его жизни, работы, о его взглядах. Лекция не может претендовать на полноту исследований об этом человеке, поскольку я знаком лишь с частью его работ. Слишком много было скрыто от нас на Западе в сложные годы XX века. Те факты, которые нам достоверно известны, говорят не только о высоком профессионализме Неговского в реаниматологии, но и об особом даре научного предвидения. Это качество было замечательно описано в статье его хорошего друга Питера Сафара [1], которая явилась частью серии публикаций под названием «Resuscitation Greats» («Великие в реаниматологии») в журнале Resuscitation. Я активно использовал именно этот источник. На примере научных открытий и озарений В. А. Неговского попытаюсь показать, насколько далеко он опередил свое время и насколько мало мы, последователи, использовали его открытия и работы небольшого числа других «пионеров» реаниматологии. На Западе реаниматология была неким «бедным родственником» других клинических специальностей. Немногие решились выбрать реаниматологию своей основной профессией. Это обусловлено тем, что научные исследования в этой области весьма сложно проводить ввиду многих причин и тем, отчасти, что мы тяжело принимаем и распространяем новые, несомненно достойные идеи, неохотно отказываемся от старых воззрений, которые основаны больше на привычках, чем на доказательствах. Нам еще многому нужно научиться, мы нуждаемся в таких личностях как В. А. Неговский: с ясным видением, 
приверженностью своему делу и объективностью. Но моя лекция посвящена не столько открытиям В. А. Неговского, сколько тому, как медленно мы их брали на вооружение, поддаваясь огромному количеству ложных представлений, и тому, как много еще предстоит сделать. Исследования В. А. Неговского, Сафара и других ученых указали нам путь, пойти по нему - наша задача.

Владимир Александрович Неговский родился в 1909 г. на Украине в большой семье, закончил институт по специальности врача в 1933 г. в Москве. Только три года спустя он создал первую лабораторию реаниматологии. Это не было минутным капризом с его стороны - это было посвящение всей жизни ученого созданию новой, ранее не распознанной, области медицины. В 1943 г. во время разрушительной Мировой войны, которая совершенно не отвечала идеалам В. А. Неговского, он опубликовал Тезисы по патофизиологии и обратимости смерти [2], а в 1961 г. на международной конференции по травматологии в Будапеште он провозгласил рождение новой науки - реаниматологии [3]. Он без устали работал над развитием новой науки и распространил ее влияние далеко за пределы неотложных состояний. Концепция постреанимационной болезни, которая стала доступной на Западе лишь в 1983 г. [4], явилась еще одной вехой для ученых-реаниматологов. В. А. Неговский продолжал активно работать до самого конца жизни.

За период деятельности, протяженностью более двух третей века, В. А. Неговский опубликовал более 300 работ. К сожалению, лишь малая их часть доступна в Западной Европе. Его работа была проведена до того, как чудеса Интернета смогли, наконец, сломать лингвистические и национальные барьеры. Масштаб его [В. А. Неговского] деятельности был поистине огромным, что ясно из приведенного ниже списка основных тем, по которым, насколько мне известно, были публикации. Но их может быть гораздо больше.

- Асфиксия новорожденных.

- Биполярная дефибрилляция (за 30 лет до того, как она распространилась на Западе).

- Социальные катастрофы и сопутствующие им спасательные работы.

- Диагностика смерти мозга.

- Электротравма.

- Наружная компрессия легких (40-е гг.).

- Кровотечение.

- Гипотермия (60-е гг.).

- Инфаркт миокарда.

- Терминальные состояния.

- Проблема органного донорства.

- Неотложные состояния при беременности.

- Реперфузионное повреждение.

- Шок.

- Травма.
В. А. Неговский различал в своих работах две стадии того, что мы на Западе называем оживлением [resuscitation]. Острую фазу он называл (дословно) «реанимация». Но более важным для него было расширенное понимание термина «реаниматология», которое включало в себя как профилактику, так и лечение терминальных состояний и постреанимационной болезни, то есть то, что до сих пор игнорировалось другими. Профилактика терминальных состояний стала распространенной за пределами России и Восточной Европы лишь недавно, что связано с развитием Команд Неотложной Медицинской Помощи, которые широко распространились после публикаций в Австралии [5].

Реаниматология, как наука, занимается многими аспектами контроля патофизиологических процессов.

- Контроль сосудистой коагулопатии.

- Контроль вентиляции.

- Контроль аритмий.

- Контроль гемодинамики.

- Контроль температуры.

- Контроль метаболических нарушений.

- Контроль остаточной ишемии.

- Контроль остаточной электрической нестабильности.

Все эти аспекты тесно связаны с современной реаниматологической наукой. Но если бы выдающийся вклад В. А. Неговского в науку был воспринят более широко, то и мировой прогресс пошел бы быстрее. История реаниматологии полна примерами того, как настоящие прорывы в науке были или просто не замечены, или использовались короткое время, а затем были незаслуженно забыты [6]. Интересно и полезно посмотреть на эту проблему более детально с другой стороны: мы можем не принимать все воззрения В. А. Неговского, но необходимо признать, что многие из его идей далеко опередили свое время. Даже сейчас в Западной Европе доступ к публикациям В. А. Неговского ограничен: несомненно, что многие даты, которые мы приписываем его блестящим идеям на основании публикаций, доступных нам, ошибочны, поскольку данные работы появились на его Родине гораздо раньше.

Контроль сосудистой коагулопатии. Неговский дал следующее интересное определение коагулопатии в одной из своих публикаций 1974 г. в Американском издании [7]:

«При остановке кровообращения значительно ускоряется свертьвание крови, и в коагулограмме ... появляются характерные черты гиперкоагуляции... Некоторье изменения коагулограммы не исчезают, и они характерны для пред-тромбозного состояния».

Только в последнее время ученые начинают признавать влияние коагулопатии на исход остановки сердца. Однако даже 30 лет назад эта идея не была 
чем-то новым. В 1954 г. Кромвель с коллегами [8] описал тромбообразование в микрососудах, а два года спустя та же группа ученых показала, что введение стрептокиназы может увеличить выживаемость собак с индуцированной остановкой кровообращения [9]. Но только в 1995 г. Фишер и Хоссман снова обратили внимание научной общественности Запада на значимость феномена «no-reflow» после экспериментальной остановки сердца [10]. В 1997 г. этот феномен был признан важнейшим осложнением внебольничной остановки сердца [11] и было описано массированное образование фибрина как препятствие на пути восстановления эффективной циркуляции. Даже после обнаружения роли внутрисосудистого свертывания крови в патофизиологии остановки сердца, клиницисты неохотно применяли фибринолиз, поскольку у пациентов практически всегда обнаруживались сдавления грудной клетки: данную травму считали серьезным фактором риска развития кровотечения. Но со временем был накоплен опыт по применению фибринолиза при инфаркте миокарда, осложненном на начальном этапе остановкой сердца. Было обнаружено, что риск кровотечения в данной ситуации и в случае короткой [12] и длительной сердечно-легочной реанимации мал [13]. Это дало толчок предварительным исследованиям фибринолиза в качестве нового обязательного метода лечения остановки сердца [14, 15]. У пациентов, выживших после остановки сердца и получавших терапию фибринолитиками, неврологические показатели были лучше $[16,17]$. В настоящее время проводится большое международное исследование эффективности фибринолиза при остановке сердца, не поддающейся неотложной дефибрилляции [18]. Но даже если в данном исследовании будет доказана эффективность фибринолиза, многое еще остается неясным: следует ли применять фибринолиз только в случае рефрактерной остановки сердца или у пациентов, сознание которых быстро не восстанавливается; за исключением пациентов, которые быстро отвечают на дефибрилляцию? Мы могли бы уйти гораздо далыше в решении этих вопросов, если бы врачи, ежедневно имеющие дело с пациентами, у которых происходит остановка сердца, уделили должное внимание экспериментальным работам, проведенным В. А. Неговским и другими учеными несколько десятилетий назад.

Контроль вентиляции. В вопросе вентиляции у В. А. Неговского была твердая позиция, что доказывает следующая цитата [19]:

«После терминальных состояний пащиенты с поражением мозга нуждаются в длительной искусственной вентиляции. При бессознательном состоянии ранний перевод на самостоятельное дыхание является ошибкой и может быть смертелен».

Многие из нас могут вспомнить случаи из практики, когда из-за невозможности проведения искусственной вентиляции, в случае остановки сердца, с расстройствами дыхания или из-за преждевременного прекращения вентиляционной поддержки, восстановление пациентов ухудшалось. Точка зрения В. А. Неговского здесь заслуживает особых пояснений. Респираторная поддержка тоже таит в себе опасности, на которые обратили внимание совсем недавно. Это касается применения гипервентиляции. Результаты экспериментальных работ [20] и клинических наблюдений [21] диктуют нам необходимость ограничивать неврологическое повреждение. Но вопрос сужения сосудов мозга в ответ на гипервентиляцию все еще порождает множество споров: большинство специалистов в настоящее время полагает, что гипервентиляции следует избегать после черепно-мозговой травмы [22] и остановки сердца [23]. Гипервентиляция у пациентов с остановкой сердца таит в себе особые опасности: неадекватная вентиляция может ограничить количество сокращений легких, снизить давление диастолической перфузии миокарда и ограничить системный кровоток путем увеличения внутригрудного давления, вызвать дыхательный алкалоз, который сдвигает кривую диссоциации кислорода влево [24]. И это не просто теоретические рассуждения. Замечено, что парамедики слишком увлекаются режимами вентиляции, которые в условиях эксперимента вызывают неблагоприятный исход [25]. В. А. Неговский, несомненно, согласился бы с тем, что не следует распространять тезис о неоспоримой важности рациональной искусственной вентиляции на гипервентиляцию только лишь на том основании, что если принцип хорош, то, чем чаще его применять, тем лучше (это не совсем так).

Контроль аритмий. Изучение контроля аритмий сконцентрировано, главным образом, на вопросе дефибрилляции, поскольку именно в этой области можно добиться реального успеха. В этом вопросе В. А. Неговский снова шагнул далеко вперед от своих западных коллег. Данная цитата подтверждает его интерес к этой проблеме [26].

«Так как электроимпульсная терапия оказывает негативное воздействие на миокард, ведется поиск путей снижения разряда дефибриллящии при сохранении ее эффективности. Был найден и использован метод, который может послужить основой для создания дефибрилляторов, генерирующих биполярный импульс».

В. А. Неговский цитирует работу своих сотрудников Н. Л. Гурвича и В. А. Макарычева [27]. Эта работа появилась за 20 лет до того, как биполярная дефибрилляция стала популярна на Западе [28]. Отвлекаясь от основной темы, можно сказать, что в эти годы изучение контроля аритмий по многим аспектам было недостаточно. Через много лет стало понятно, что антиаритмические 
препараты играют небольшую роль в профилактике аритмий, особенно препараты I класса, обладающие аритмогенным эффектом [29]. В смысле эффективности лекарств, можно отметить, что в случае тяжелых нестабильных ритмов мы можем быть уверены в эффективности кардиоверсии (в современных условиях идеально использование кардиоверсии с биполярными разрядами), также у нас есть достоверные доказательства эффективности атропина. Амиодарон является препаратом выбора при тахикардиях [30], но у нас нет четких доказательств того, что он увеличивает выживаемость больных при острых состояниях. Использование бета-блокаторов недостаточно. В большинстве случаев врачи игнорируют использование препарата эсмолол, который хорошо зарекомендовал себя при многих тахиаритмиях. Недавнее исследование в одном из медицинских центров Великобритании продемонстрировало, что различные $\beta$-блокаторы использовались лишь у 11\% пациентов, выживших после остановки сердца [31]. Итак, использование $\beta$-блокаторов предполагает выживаемость пациентов после остановки сердца, что было продемонстрировано в недавно проведенном исследовании с использованием множественного регрессионного анализа [32], и их безопасность при аккуратном применении в случае сердечной недостаточности, даже при наличии гипотензии, не вызывает сомнений [33]. Не думаю, что В. А. Неговский, с его гениальным даром, удивился бы неправильному применению одного из немногих эффективных методов лечения злокачественных аритмий, хотя, несомненно, я не могу рассуждать о конкретных комментариях, которые бы он дал на этот счет.

Контроль гемодинамики. У В. А. Неговского были четкие представления по этому вопросу, чего и следовало ожидать, учитывая его известный интерес к изучению вопроса травмы. В данном случае его воззрения не полностью соотносятся с современными [7].

«Известно, что длительная гипотензия, особенно если ей предшествует невосполненная потеря крови, может привести к необратимому поражению жизненно важных органов даже до того, как прочзошла клиническая смерть».

До сих пор вроде бы все было ясно, тем не менее, этот пункт требует дополнительного разъяснения. Данный тезис подразумевает рекомендацию по использованию артериальной трансфузии на фоне больших доз кортикостероидов при неадекватности венозного доступа. Лишь немногие согласятся с тем, что артериальная трансфузия может быть полезна в особых ситуациях, а роль кортикостероидов по меньшей мере спорна. Последние исследования показали, что модное во многих стра- нах их применение при черепно-мозговой травме приносит больше вреда, чем пользы [34]. Наше уважение к Владимиру Александровичу не должно означать, что мы будем некритично воспринимать все его утверждения. Он и сам не пожелал бы этого. Но в вопросе контроля аритмий мы недалеко ушли от В. А. Неговского и часто выбирали неправильные направления. Значимость оптимального объема наполнения при гипотензии ясна, но конкретное значение этого объема может различаться при разных патологиях. Достаточно спорным остается и эффект вазоактивных препаратов (норадреналин, добутамин, дофамин, амринон, сальбутамол), которые изучаются с большим энтузиазмом и имеют много влиятельных защитников. Последнее мнение на этот счет таково [35]: не существует доказательств эффективности какого-либо прессорного препарата, но большинство врачей для лечения постоянной гипотензии с систолическим давлением меньше 70 мм рт. ст. обычно использует добутамин. Сердечный выброс важнее кровяного давления! Это огромное поле для исследования.

Контроль температуры. Этот вопрос до сих пор остается весьма актуальным и активно дискутируемым. У В. А. Неговского, однако, были представления, которых не хватало Западу. Первая его публикация по этому вопросу, доступная нам, была в 1962 г. в Нью-Йорке [36] под названием «Реанимация и искусственная гипотермия». Мне не удалось получить копию этой монографии, но одно только название доказывает, что В. А. Неговский был пионером терапевтической искусственной гипотермии и его идеи долго не могли найти применения в медицине. В 1954 г. экспериментально было показано, что метаболизм мозга повышается на 7\% при повышении температуры на каждые $1^{\circ} \mathrm{C}$ [37]. Неблагоприятный исход после остановки сердца был отмечен у пациентов с лихорадкой [38]. Несколько лет спустя были получены положительные результаты использования контролируемой гипотермии у больных в коме [39, 40], данный вопрос был хорошо освещен в New England Journal of Medicine за 1961 г. [41] Рандомизированные исследования по применению этого метода у пациентов с остановкой сердца были опубликованы в 2002 г. [42, 43]. Продемонстрировано улучшение функции мозга и снижение летальности. В том же году был сформулирован принцип ILCOR [44], который заключает в себе следующий совет: «взрослый пациент без сознания, у которого обнаруживается спонтанное кровообращение после внегоспитальной остановки сердца должен быть охлажден до $32 / 34^{\circ} \mathrm{C}$ на $12-24$ ч. в случае, если начальным ритмом была желудочковая фибрилляция», также было добавлено: «...такое охлаждение может быть полезно при лечении других нарушений ритма у больных с внутрибольничной остановкой сердца». Но даже сегодня этот метод лечения не получил широкого распространения 
в моей стране. Почему же мы так медленно учимся? Это не связано со сложностью технологий. Наряду со сложными методами можно применять и относительно простые. Такими методами являются те, которые описаны в рекомендациях ILCOR: наружное охлаждение тела с использованием пакетов со льдом; наружное локальное охлаждение головы с использованием особых шлемов; внутрисосудистые вливания, например, охлажденного физиологического раствора; перитонеальное или плевральное охлаждение с использованием внутрисосудистых теплообменников. Однако вопрос контроля температуры в критической медицине не сводится лишь к ее снижению. Исследования показывают, что рациональное повышение температуры тела - хотя бы до нормального уровня - играет роль в борьбе с дисфункцией тромбоцитов при травме, сопровождающейся кровотечением [45]. Данный вопрос изучен очень плохо и содержит в себе много противоречий, в то время как вопрос контроля температуры тела был забыт, с энтузиазмом изучались и применялись другие методы защиты головного мозга: использование барбитуратов [46], стероидов [47], блокаторов кальциевых каналов [48, 49]. В конечном счете, ни один из названных методов не принес успеха.

Контроль метаболических нарушений. Концепции В. А. Неговского выходили за рамки того, что мы понимаем под расстройствами метаболизма. Он, совместно с И. О. Закс, писал [50].

«Исследования, проводившиеся в нашем институте в течение многих лет, показывают, что любое терминальное состояние, независимо от его этиологии, сопровождается «токсемией». Чем сильнее или длительнее гипоксия тканей, тем выше уровни многочисленных токсических продуктов в крови».

Таким образом, не забывая о важности кислотно-щелочного равновесия, он показал потенциал использования гемосорбции для удаления токсичных метаболитов. И в этом вопросе В. А. Неговский обогнал свое время. До недавнего времени многие на Западе не очень верили в успешность удаления токсичных метаболитов из крови. Но, возможно, отношение изменится. В 2002 г. Вайсфельдт и Бэкер [51] описали три фазы реанимации после остановки сердца: электрическую, циркуляторную и метаболическую. Последняя фаза созвучна концепциям В. А. Неговского. В вопросе изучения метаболической стадии эти авторитетные ученые выдвинули гипотезу об использовании шунтирования для разведения токсичных метаболитов. Однако эффективность данного метода следует еще доказать. Метаболические нарушения после остановки сердца возникают по нескольким причинам: некоторые - вследствие воздействия ишемии на ткани, некоторые - вследствие физиологических реакций, другие - вследствие лечения. Эндогенное высвобождение катехола- минов и стероидов вызывает одно важное осложнение - гипергликемию, которая часто усиливается при применении адреналина. До недавнего времени, на это мало обращали внимание, несмотря на важность проблемы. Гипергликемия была названа маркером повышенной смертности после остановки сердца $[52,53,54]$ и предвестником смерти после инфаркта миокарда [55] и инсульта [56], но ранее ее считали лишь побочным эффектом, который не мог играть причинную роль в патогенезе перечисленных заболеваний. Однако в 2003 г. два исследования [32, 57] с использованием мультивариантного анализа показали, что гипергликемия имеет независимое влияние на смертность. Только в 2001 г. [58] появилась первая публикация, авторы которой пытались изучить значение контроля гликемии крови у взрослых реанимационных больных. Специальных исследований по данной проблеме у пациентов с остановкой сердца проведено не было.

Контроль остаточной ишемии. Хотя В. А. Неговского данный вопрос интересовал в ракурсе постреанимационной болезни, эффективные методы контроля остаточной ишемии появились лишь значительно позже. На самом деле, важность ишемии и недавней ишемии как причины внезапной остановки сердца долгое время была неясна. Причины тому понятны. В случае внезапной смерти патологические изменения, характерные для инфаркта, не успевают развиться, а достоверная идентификация свежего тромба в коронарной артерии настолько трудоемка, что не может быть использована в эпидемиологических исследованиях. Обширный опыт прегоспитальной реанимации в Сиеттле [59] показал, что свежая ишемия сыграла определенную роль в патологии лишь половины выживших пациентов. У остальных пациентов не было выявлено никаких клинических, электрокардиографических или ферментных доказательств свежей ишемии. Но выжившие пациенты могли не представлять адекватно всю популяцию больных с остановкой сердца. Кроме того, эти данные предвосхитили понимание процесса разрыва бляшки и развития электрических событий, которые могут следовать за такими осложнениями, как эмболия тромбоцитами. В Париже Сполдинг с коллегами [60] пролил свет на изучение этой проблемы. Они провели коронарную ангиографию у 75 пациентов (сразу после их поступления) с внегоспитальной остановкой сердца в возрасте от 30 до 75 лет вне зависимости от восстановления их сознания. Было установлено, что в их выборке ишемия явилась самой частой причиной внезапной остановки сердечной деятельности, хотя некоторые неточности все равно могли произойти, вследствие изучения ими только выживших пациентов (у умерших с большей вероятностью можно было обнаружить тяжелую ишемию в момент приступа). У $48 \%$ обследованных была выявлена явная свежая закупорка 
коронарной артерии, у 21\% - вероятность свежей закупорки. Другие значимые коронарные заболевания были обнаружены в 2\%. В 11\% случаев не были обнаружены клинические признаки коронарной патологии, несмотря на то, что ангиографически их удалось выявить, что еще больше доказывает необходимость тщательного обследования всех выживших после внезапной остановки сердца. Об этом мы поговорим в следующем разделе.

Контроль остаточной электрической нестабильности. Дефибрилляция в значительной степени решает эту проблему в острых стадиях реанимации. Но доступные методы лечения электрической нестабильности в постреанимационном периоде возникли в годы завершения рабочей деятельности Владимира Александровича Неговского, и мне неизвестны его публикации по этой теме. Несмотря на то, что существуют мощные методы предотвращения рецидива злокачественных аритмий у выживших после остановки сердца, их использование во многих Европейских странах недостаточно. Вестон и коллеги в 1993 г. [61] сообщили о том, что в Уэллсе только 3 пациента из 53 выживших после внезапной остановки сердца прошли электрофизиологическое исследование и никому из них не имплантировали дефибриллятор; 32 пациента не было направлено к кардиологу. В похожем исследовании 2000 г. в Англии Пеппер и коллеги [31] показали, что в группе из 52 пациентов (другая группа) только 8 подверглась электрофизиологическому исследованию, 6-и пациентам имплантировали дефибриллятор, но 29 пациентов не было проконсультировано кардиологом. Незначительно отличается ситуация в Швеции [62]. В большинстве Европейских стран остро стоит проблема стоимости дефибрилляторов. Согласно сообщению 2004 г. [63] частота использования дефибрилляторов в США была 169 на миллион популяции; в Дании частота их использования больше, чем где либо в Европе, и составляет 28\% от цифр в США, а во всех остальных странах - ниже $25 \%$ от частоты в Америке. Это может быть неизбежным, или этого можно избежать, но множество пациентов, выживших после внегоспитальной остановки сердца, не получают должного лечения.

Что же следует предпринять? Одна стратегия решения данной проблемы неприменима ко всем случаям [64], но у нас есть достоверные доказательства того, что большинство случаев внегоспитальных внезапных остановок сердца происходит вследствие патологии коронарных артерий. Те пациенты, которые недавно перенесли инфаркт, подвергаются, вероятно, меньшему риску рецидива, чем остальные [59], но тем не менее ангиографию им необходимо произвести, даже если есть веские доводы против детального обследования; чрескожное исследование будет проведено в большинстве случаев и, возможно, его будет достаточно для сня- тия опасности возникновения злокачественных ишемических аритмий. Ситуация будет менее ясной у выживших с документированной ишемией, но без достоверных признаков свежего ишемического события. В таком случае причина недавней остановки сердца останется неясной и, в идеале, будет проведено электрофизиологическое исследование с перспективой имплантации в дальнейшем дефибриллятора. Это предпочтительный алгоритм для всех случаев, когда необходимо детальное обследование, если ишемия не является явным этиологическим фактором.

Итак, становится понятно, что нам нужно еще много сделать для улучшения ведения пациентов после неотложной терапии остановки сердца. В 2004 г. следует серьезно изучать роль короткодействующих $\beta$-блокаторов в неотложном периоде после остановки сердца, и быть более позитивно настроенными по отношению к пролонгированным пероральным препаратам. Следует получить реальные доказательства эффективности использования адреналина в лечении рефрактерной остановки сердца и применения вазопрессоров против гипотонии; прояснить роль фибринолиза в лечении остановки сердца даже по завершению международного исследования, проводимого в настоящее время. Неясно соотношение риск-эффект при применении амиодарона в лечении злокачественных тахиаритмий на фоне недавней остановки сердца или без нее. Следует выработать показания к применению гипотермии, особенно важно решить вопрос выбора метода охлаждения и оптимального времени начала терапии. Следует более четко определить безукоризненный метод контроля уровня глюкозы крови после остановки сердца, широко осветить потенциальную роль концентрации глюкозы крови после остановки сердца, изучить расстройства в системе других токсических метаболитов, внедрить как можно шире использование ангиографии, чрескожных исследований коронарных артерий, электрофизиологических методов и имплантируемых дефибрилляторов. Мы находимся на пороге улучшения как прегоспитального ведения больных с остановкой сердца, так и больничного лечения. Нам необходима полная самоотдача. У В. А. Неговского она была. Простое перечисление его интересов в реаниматологии поражает. Но есть еще два, о которых я не упомянул. Он тонко чувствовал философию своей науки. В качестве примера приведу следующую цитату 1986 г. [65]:

«Жизнь есть наш величайший дар. Мы должны продолжать бороться за людей, стоящих на грани жизни и смерти. Здесь заключается значение и цель нашей науки».

Всегда важным для него было стремление к миру [66]. 
«Наша борьба за сохранение жизни имеет смысл, если мы живем в мире и предотвращаем ядерные и звездные войны».

За жизнь многих из нас Европа сильно изменилась. Войны, которые за нашу жизнь так исказили континент, должны быть немыслимыми в будущем. Но в мире нет мира. Конфликты, которые хотелось бы разрешить разумными переговорами, являются оправданием для применения оружия, еще более мощной потенциально разрушительной силы. Даже в пределах наших стран бесчувствен-

\section{От редакции}

19 марта 2005 г. исполнилось 96 лет со дня рождения В. А. Неговского. В память о великом учёном редакция журнала публикует лекцию известного английского ученого - реаниматолога Д. Чемберлена о В. А. Неговском, с которой он выступил в Будапеште на VII Научном Конгрессе Европейского Совета по реанимации в сентябре 2004 г.

Лекция Д. Чемберлена, несмотря на краткость информации за рубежом о жизни и деятельности Владимира Александровича Неговского, вызывает чувство глубокого удовлетворения. Автор неоднократно подчеркивает, что многие положения нашей науки, которые только сегодня начинают разрабатываться за рубежом, много лет назад были предметом исследования Владимира Александровича.

Начав свою деятельность с изучения умирания и восстановления жизни, он впервые предложил термин «реанимация», доказал, что смерть это процесс. А процесс можно и необходимо изучать. В результате этого изучения В. А. Неговским было доказано, что смерть может быть обратимая - «клиническая смерть» и необратимая - «биологическая смерть», что состояния человека могут быть «предтерминальными», «терминальными» и «постреанимационными» (термины предложены В. А. Неговским). Объединяют эти состояния общепатологические неспецифические реакции организма, независящие от этиологического фактора, вызвавшего критическое состояние, которые наиболее ярко выражены при полной остановке кровообращения - клинической смерти. Идентификация этиологического фактора, вызвавшего критическое состояние, и патогенеза имеет важное практическое лечебное значение лишь на ранних стадиях развития процесса, в дальнейшем она утрачивает свою специфичность ввиду сходных механизмов развития критических, терминальных и ный терроризм приносит незаслуженные боль и страдание людям, что произошло совсем недавно в России, когда школьники стали мишенями злых людей [67]. Это событие более, чем какое-либо другое, причинило всем нам сильную боль. Являясь членами Международного Совета по Реаниматологии, мы не в состоянии предотвратить все конфликты, но в наших силах создавать такую духовную атмосферу в обществе, при которой конфликты стали бы редкими и не такими разрушительными. Мы все должны быть послами мира. Это лучший способ почтить память Владимира Неговского.

постреанимационных состояний. В последующем эти реакции стали объединять в синдромы.

С учетом накопленных человечеством знаний, и, прежде всего, общей патологией и патофизиологией, В. А. Неговский обосновал и создал новую науку, которую предложил в 1961 г. назвать «РЕАНИМАТОЛОГИЕЙ», занимающейся изучением механизмов развития критических, терминальных и постреанимационных состояний, разработкой и внедрением в клиническую практику методов жизнеобеспечения, новых реанимационных технологий и мониторинга. К этим методам относятся не только сердечно-легочная реанимация, но и анестезия, искусственная вентиляция легких, гемодиализ, гипертермия, гипербарическая оксигенация, искусственное кровообращение и многие другие, способствовавшие созданию и развитию кардиохирургии, трансплантологии, нейрохирургии, полостной хирургии.

Прав Д. Чемберлен и в том, что В. А. Неговский был первым, кто выделил догоспитальный и госпитальные этапы в реаниматологии, в совершенствовании которых он видел прогресс медицины.

За рубежом сейчас все больше и больше склоняются к тому, что термин «реаниматология» отражает суть нашей науки. Специализация в ней, в отличие от хирургии и терапии, возможна не по органам и системам (гепатология, неврология,...) этиопатогенезу (травматология, онкология,..) и т. д., а по методам - уже существуют специалисты по анестезии, детоксикации, гипербарической оксигенации, искусственному кровообращению и пр.

Переполненный зал международного конгресса с большим внимание выслушал лекцию Д. Чемберлена и наградил его бурными аплодисментами. Международное признание заслуг В. А. Неговского способствовало и будет способствовать дальнейшему развитию реаниматологии. 